\title{
Reverse Flood Routing in Natural Channels using Genetic Algorithm
}

\author{
G. Zucco $^{1} \cdot$ G. Tayfur $^{2}$ - T. Moramarco $^{3}$
}

Received: 31 July 2014 / Accepted: 6 July 2015 /

Published online: 29 July 2015

(C) Springer Science+Business Media Dordrecht 2015

\begin{abstract}
Establishing a clear overview of data discharge availability for water balance modelling in basins is a priority in Europe, and in the particular in the framework of the system of Economic and Environmental Accounts for Water (SEEAW) developed by the EU Directorate-General for the Environment. However, accurate discharge estimation at a river site depends on rating curve reliability usually defined by recording the water level at a gauged section and carrying out streamflow measurements. Local stage monitoring is fairly straightforward and relatively inexpensive compared to the cost to carry out flow velocity measurements which are, in addition, hindered by high flow. Moreover, hydraulic models may not be ideally suitable to serve the purpose of rating curve extension or its development at a river site upstream/downstream where the discharge is known due to their prohibitive requirement of channel cross-section details and roughness information at closer intervals. Likewise, rainfallrunoff transformation might be applied but its accuracy is tightly linked to detailed information in terms of geomorphological characteristics of intermediate basins as well as rainfall pattern data. On this basis, a procedure for reverse flood routing in natural channels is here proposed for three different configurations of hydrometric monitoring of a river reach where lateral flow is significant and no rainfall data are available for the intermediate basin. The first considers only the downstream channel end as a gauged site where discharge and stages are recorded. The second configuration assumes the downstream end as a gauged site but only in terms of stage. The third configuration envisages both channel ends equipped to recording stages. The channel geometry is known only at channel ends. The developed model has basically four components:
\end{abstract}

\section{G. Tayfur}

gokmentayfur@iyte.edu.tr

\section{G. Zucco}

graziano.zucco@irpi.cnr.it

T. Moramarco

t.moramarco@irpi.cnr.it

1 Research Fellow, National Research Council, Research Institute for Geo-Hydrological Protection, Perugia, Italy

2 Department. Civil Engineering, Izmir Institute of Technology, Urla Izmir, Turkey

3 Researcher, National Research Council, Research Institute for Geo-Hydrological Protection, Perugia, Italy 
(1) the inflow hydrograph is expressed by a Pearson Type-III distribution, involving parameters of peak discharge, time to peak, and a shape factor; (2) the basic continuity equation for flow routing written in the characteristic form is employed; (3) the lateral flow is related to stages at channel ends. (4) the relation between local stage and remote discharge as found by Moramarco et al. (2005b) is exploited. The parameters, coefficients and exponents of the model are obtained, for each configuration, using the genetic algorithm method. Three equipped river branches along the Tiber River in central Italy are used to validate the procedure. Analyses are carried out for three significant flood events occurred along the river and where the lateral flow was significant. Results show the good performance of the procedure for all three monitoring configurations. Specifically, the discharge hydrographs assessed at channel ends are found satisfactory both in terms of shape with a Nash-Sutcliffe ranging overall in the interval (0.7550.972 ) and in the reproduction of rating curves at channel ends. Finally, by a synthetic test the performance of the developed procedure is compared to that of the hydraulic model coupled with a hydrologic model. Two river reaches are considered, the first along the Tiber River and the second one located in the Rio Grande basin which is a tributary of the Tiber River. Detailed channel geometry data are available for both the river sections. Results showed the effectiveness of the reverse flood routing to reproducing fairly well the hydrographs simulated by the hydraulic model in the three monitoring investigated configurations.

Keywords Reverse routing $\cdot$ Flood wave $\cdot$ Peak rate $\cdot$ Time to peak $\cdot$ Simulation $\cdot$ Hydrograph generation $\cdot$ Hydraulic modelling $\cdot$ River reach $\cdot$ Genetic algorithm

\section{Introduction}

Determination of flow discharge at a river site is required for water resources planning and management, and controlling floods. Discharge is obtained from the measurement of flow depth, channel width and flow velocity. For these measurements, the river section is often equipped with hydrometric sensors for flow depth measurements, and cableway and current meter for velocity measurements and a topographic surveying is carried out for channel crosssection (Moramarco et al. 2004). Once a reliable rating curve is obtained for a river section then flow stage, which is fairly inexpensive and easy to measure, is needed (Perumal et al. 2007; Sahoo 2013; Sahoo et al. 2014).

Most often however only a single station on a natural river is equipped to record flow rate. Yet, the knowledge of hydrograph not only at the gauging station but also at upstream/ downstream sections of the station may be fundamental to achieve the environmental objectives under the Directive 2000/60/CE and 2007/60/CE addressing the water resource management and flood risk mitigation, respectively. Indeed, not always discharge data are available at sites that are crucial to address the sustainable use of water resources and design flood and for them it would be possible to leverage hydraulic information of a gauged site located upstream/ downstream far away. However, discharge hydrograph at the gauging station may have quite different characteristics than the ones at the upstream/downstream, sections due to the lateral inflows, drainage area, channel storage, and effects of resistance (D'Oria and Tanda 2012). Therefore, to estimate discharge hydrograph at these ungauged river sites, coupled hydrologic and hydraulic models may be applied (Moramarco et al. 2005a). However, the lack of information in terms of rainfall and primarily of topographical data of channels inhibits their use. 
In this context, a procedure of determining an upstream hydrograph based upon the knowledge of downstream hydrograph and the hydraulics characteristics of the river reach, known as the "reverse routing process" can be applied (Das 2009; D'Oria and Tanda 2012). One way of performing reverse routing is to solve Saint Venant equations based upon the knowledge of discharge series at the end of the river reach, the initial condition along the reach, and boundary condition at the downstream end (Eli et al. 1974; Szymkiewicz 1996; Dooge and Bruen 2005; Bruen and Dooge 2007; Artichowicz and Szymkiewicz 2009). Eli et al. (1974), who analyzed a real case between two monitoring stations on James River reach in Virginia, USA, had to pay attention to computation in order to have positive outcome. They detected numerical instabilities for low discharge values. Szymkiewicz (1996), who employed the implicit method to solve the governing equations, witnessed the strong oscillations for sharp hydrographs. Dooge and Bruen (2005) found that parameters had great influence on the numerical model and instabilities can arise over a wide range of channel slopes. In their another numerical test study (Bruen and Dooge 2007), they observed high fluctuations in the inverse routing of step waves or high frequency waves and a forward routing of obtained hydrographs was not able to reproduce the original routed waves. Das (2009) employed linear and nonlinear Muskingum method for reverse flow routing. He suggested that there is a need for separate calibration of Muskingum methods. Aforementioned studies applied the reverse flood routing for simplified cases such as subcritical flow and regular riverbeds, in addition to the shortcomings outlined above (D'Oria and Tanda 2012). The numerical solution of Saint Venant equations, and Muskingum models would require however substantial data on river reach geometry, roughness, and parameter estimation for real case applications. Most recently, D’Oria and Tanda (2012), by employing Bayesian Geostatistical Approach, performed reverse flood routing. Their methodology treats the upstream hydrograph as a random function that is defined through statistical properties. Some degree of continuity and smoothness is imposed on the shape of the unknown hydrograph. They route the upstream hydrograph by the hydraulic model many times in downstream direction to produce downstream hydrograph as close as possible. In routing the model, the information on the shape of river cross sections, bed slope, river reach length, hydraulic structures and so on is required. The forward model (one-dimensional Saint Venant equations) is considered already implemented and calibrated and able to describe the hydraulic routing process (D’Oria and Tanda 2012). They performed many synthetic test scenarios for various cases such as supercritical flows in prismatic and non-prismatic irregular channels. Although, the model of D'Oria and Tanda (2012) can be applied to more general cases, it still has the similar requirements as the previous models and its applicability might be, overall, diminished considering that the topographical cross-section surveys are costly and not always available. In summary, the literature review shows us that the existing models developed so far require numerical solutions of the channel flow equations, substantial data and parameter estimation.

Based on that, this study however proposes a new methodology such that for estimating the discharge at upstream section, downstream hydrograph is all that is needed regardless the size of the intermediate basin and no needs for topographical cross-section data along the river reach except at channel ends. It employs the basic continuity equation for flood routing. An additional investigation is also proposed for the case wherein stage hydrographs are recorded at channel ends with significant lateral flows. For the case of which only hydrograph is recorded at downstream end, the upstream hydrograph is treated as Pearson Type III distribution which has parameters of peak rate, time to peak, and hydrograph shape. The continuity 
equation written in a characteristic form is used to express the downstream discharge and lateral flow. All the optimal values of the parameters and coefficients are obtained by the genetic algorithm method while producing the downstream hydrograph as close as possible. This simple methodology and has no restrictions and it is applied to real river reaches. The procedure is verified by using hydrographs recorded at three equipped river reaches belonging to the Tiber River, central Italy, along with a synthetic test based on the application of a hydraulic and hydrologic model.

\section{Reverse Flood Routing Model}

The reverse flood routing model developed in this study has basically four components. The first component is the formulization of the inflow hydrograph. For the case in which gauged site is at downstream end, following Moramarco et al. (2008), Pearson Type III distribution is employed for runoff:

$$
Q_{u}(t)=Q_{p_{u}} \cdot\left(\frac{t}{t_{p_{u}}}\right)^{\left(\frac{1}{y-1}\right)} \exp \left(\frac{1-\frac{t}{t_{p_{u}}}}{y-1}\right)+Q_{b}
$$

where, $Q_{u}(t)$ is upstream flow discharge, $Q_{p_{u}}$ is upstream peak discharge, $Q_{b}$ is the baseflow, $t_{p_{u}}$ is upstream time to peak and $\gamma$ is hydrograph shape parameter computed assuming that the dimensionless shape of hydrograph at channel ends is equal. As it can be understood from Eq. (1), there are three parameters to be estimated, namely $Q_{p_{u}}, t_{p_{u}}$ and $Q_{b}$.

Second component of the model is the continuity equation for flood wave routing that can be expressed as:

$$
\frac{\partial A}{\partial t}+\frac{\partial Q}{\partial x}=q
$$

where $q$ is the lateral flow and $A$ is the cross-sectional flow area.

Considering the characteristic method, Eq. (2) can be rewritten in two different ways, yielding:

$$
\left\{\begin{array}{l}
\frac{d Q}{d t}=c q \\
\frac{d A}{d t}=q
\end{array}\right.
$$

both hold along the characteristic $d x / d t=c$, where $c=L / T_{l}$ is the celerity approximated by the ratio between the channel length, $L$, and the mean wave travel time, $T_{l}$.

Along the characteristic line, assuming $c \cong L / T_{l}$, by arranging Eq. (3) one obtains:

$$
Q_{d}(t)=\left[Q_{u}\left(t-T_{l}\right)\right]+L q
$$

where, $Q_{d}(t)$ and $Q_{u}(t)$ is the downstream and upstream discharge, respectively. While from Eq. (4), it yields:

$$
\frac{\left[A_{d}(t)-A_{u}\left(t-T_{l}\right)\right]}{T_{l}}=q
$$


$A_{d}(t)$ and $A_{u}(t)$ are the downstream and upstream cross-sectional flow area, respectively. As a consequence, the downstream discharge can be obtained by substituting Eqs. (6) into (5):

$$
Q_{d}(t)=\left[Q_{u}\left(t-T_{l}\right)\right]+\left(\frac{L}{T_{l}}\right) \cdot\left[A_{d}(t)-A_{u}\left(t-T_{l}\right)\right]
$$

$A_{u}(t)$ is estimated by the power law as $A_{u}(t)=\xi Q_{u}(t)^{\psi}$, therefore:

$$
Q_{d}(t)=\left[Q_{u}\left(t-T_{l}\right)\right]+\left(\frac{L}{T_{l}}\right) \cdot\left[A_{d}(t)-\xi \cdot Q_{u}\left(t-T_{l}\right)^{\psi}\right]
$$

Three different configurations of river reach hydrometric monitoring with available topographical surveys data are considered for the analysis:

1. Stage (Flow Area) and discharge hydrographs are recorded at downstream end and discharge is assessed at upstream end.

2. Stages (Flow Areas) are recorded at downstream end and discharge is estimated at both channel ends. In this case, it is assumed $A_{d_{\text {model }}}(t)=\lambda \cdot Q_{d}(t)^{\delta}$.

3. Stages (Flow Areas) are recorded at channel ends and discharge is estimated at both sites. This configuration is similar to that investigated by Perumal et al. $(2007,2010)$ except for the lateral flows which are significant in our study.

For the third configuration, a power law is used for the inflow hydrograph, $Q_{u}(\mathrm{t})=x A_{u}(t)^{y}$, while the Rating Curve Model (RCM), developed by Moramarco et al. (2005b), is used for estimating $Q_{d}(t)$, as:

$$
Q_{d}(t)=a \cdot\left[\frac{A_{d}(t)}{A_{u}\left(t-T_{l}\right)} Q_{u}\left(t-T_{l}\right)\right]+\beta
$$

where $\alpha$ and $\beta$ are parameters. The model allows to relate local stages to hydraulic conditions recorded at a river site far away. In particular, it was found that the optimal $T_{l}$ is the one for which the maximum coefficient of determination, $R^{2}$, is obtained between the two quantities $Q_{d}(t)$ and $\frac{A_{d}(t)}{A_{u}\left(t-T_{l}\right)} \cdot Q_{u}\left(t-T_{l}\right)$. We refer the reader to Moramarco et al. (2005b) and Barbetta et al. (2012) for more details.

\section{Genetic Algorithm}

Genetic algorithm $(G A)$ is a nonlinear search and optimization method inspired by biological processes of natural selection and the survival of the fittest. It makes relatively few assumptions and do not rely on any mathematical properties of the functions such as differentiability and continuity and this makes it more generally applicable and robust (Liong et al. 1995; Goldberg 1999).

Basic units of GA consist of "bit", "gene", "chromosome" and "gene pool". Gene consisting of bits [ 0 and 1$]$ represents a model parameter (or a decision variable) to be optimized. The combination of genes forms the chromosome each of which is a possible solution for each variable. Finally, set of chromosomes form the gene pool. 
The main GA operations basically consist of "generation of initial gene pool", "evaluation of fitness for each chromosome", "selection", "cross-over", and "mutation". Figure 1 shows the flowchart for the optimization algorithm. Initially, $\mathrm{N}$ numbers of chromosomes are randomly generated. Then, fitness of each generated chromosome is evaluated by Eq. (10) as follows:

$$
F\left(C_{i}\right)=\frac{f\left(C_{i}\right)}{\sum_{1}^{N} f\left(C_{i}\right)}
$$

where $C_{i}$ is chromosome $i, F\left(C_{i}\right)$ is fitness value of chromosome $i$ that is the percentage of variable in the pool, $f\left(C_{i}\right)$ is value of objective function evaluated for chromosome $i$, and $N$ is the number of chromosomes in the gene pool.

In the next step, weak chromosomes are eliminated by the selection process. The selected chromosomes are paired and then subjected to crossover and mutation operations to generate new individuals. Thus far, a single iteration is completed in the optimization procedure. The iterations are continued until all the chromosomes converge to the optimal solution.

The details of GA can be obtained from Goldberg (1989) and Tayfur (2012), among others.

GA has recently found wide application in water resources engineering (Sen and Oztopal 2001; Jain et al. 2004; Guan and Aral 2005; Singh and Datta 2006; Cheng et al. 2006; Aytek and Kisi 2008; Tayfur 2009), flood forecasting (Wu and Chau 2006; Tayfur and Moramarco 2008; Tayfur et al. 2009) and rainfall-runoff modeling (Cheng et al. 2002, 2005; Hejazi et al. 2008; Tayfur and Singh 2011).

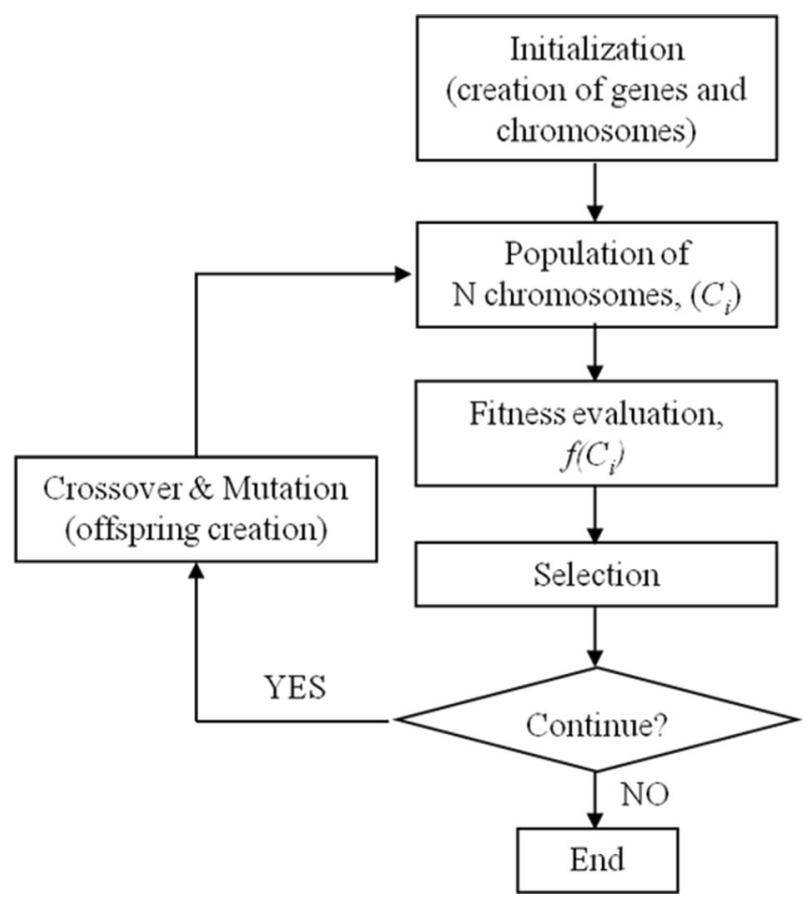

Fig. 1 Flowchart showing the principle of GA optimization algorithm 
GA can minimize (or maximize) an objective function under some specified constraints. For the purpose of this study, the GA is employed to obtain optimal values of the parameters and coefficients of the models presented in Table 1 by minimizing the mean absolute error $(M A E)$ objective function, according to the considered monitoring configuration. Specifically, for Model (1) $M A E$ is:

$$
M A E=\frac{1}{N} \cdot \sum_{i=1}^{N}\left|X_{\text {model }}-X_{\text {observed }}\right|
$$

where $N$ is number of observations and $X$ is the variable of interest.

The mean absolute error (MAE), illustrating the possible maximum deviation, is one of the commonly employed error functions in the literature (Cheng et al. 2005). According to Taji et al. (1999), to minimize the deviation, the absolute error may sometimes be better than the square error.

In fact, the absolute error function has the advantage that it is less influenced by anomalous data than the square error function (Taji et al. 1999).

The reverse flood routing procedure in this study is summarized for each configuration as in the sequel:

MODEL 1 - Stages and discharges recorded at downstream end:

1. Assign initial values for parameters and coefficients: $Q_{p_{u}}, t_{p_{u}}, \xi, \psi, Q_{b}, T_{l}$;

2. Compute upstream hydrograph $Q_{u}(t)$ by Eq. (1);

3. Compute upstream flow area $A_{u}(t)=\xi Q_{u}(t)^{\psi}$;

4. Compute downstream hydrograph $Q_{d}(t)$ by Eq. (8);

5. Compute the mean absolute error $(M A E)$, Eq. (11), for the simulated downstream discharges; in this case $X=Q_{d}$;

6. Check the coefficient of determination, $R^{2}$, between $Q_{d_{o b s}}(t)$ and $\left\{\frac{A_{d_{\text {obs }}}(t)}{A_{u_{\text {mod }}}\left(t-T_{l}\right)} \cdot Q_{u_{\text {mod }}}\left(t-T_{l}\right)\right\}$ of Eq. (9);

This step is of paramount importance for the estimation of $T_{l}$, considering that Moramarco et al. (2005b) showed that floods in natural rivers exhibit a linear correlation above the two quantities as much larger as the wave travel time is the correct one.

7. Continue minimizing the error, while trying to reach the optimal values of the parameters and coefficients in step 1), by performing steps from 2) to 6). Considering the computational efforts, a threshold of $3 \%$ has been selected.

8. Stop the iterations when the global minimum error is reached and the maximum coefficient of determination is obtained for Eq. (9). Therefore, optimal values for parameters and coefficients are obtained and $Q_{u}(t)$ is assessed by Eq. (1).

Table 1 Parameters and coefficients of reverse flood routing models, (for symbol see text)

\begin{tabular}{|c|c|c|c|c|c|c|c|c|}
\hline Model & \multicolumn{7}{|c|}{ Parameters and coefficients } \\
\hline 1 & $\mathrm{Q}_{\mathrm{p}}$ upstream & $\mathrm{t}_{\mathrm{p}}$ upstream & \multicolumn{3}{|c|}{$\xi$} & $\psi$ & $\mathrm{Q}_{\mathrm{b}}$ & $\mathrm{T}_{1}$ \\
\hline 2 & $\mathrm{Q}_{\mathrm{p}}$ upstream & $\mathrm{t}_{\mathrm{p}}$ upstream & $\xi$ & $\psi$ & $\mathrm{Q}_{\mathrm{b}}$ & $\lambda$ & $\delta$ & $\mathrm{T}_{1}$ \\
\hline 3 & $\alpha_{\mathrm{RCM}}$ & $\beta_{\mathrm{RCM}}$ & \multicolumn{5}{|c|}{$\mathrm{x}$} & \multicolumn{5}{c|}{$\mathrm{y}$} \\
\hline
\end{tabular}


MODEL 2 - Stages recorded at downstream end:

1. Assign initial values for parameters and coefficients: $Q_{p_{u}}, t_{p_{u}}, \xi, \psi, Q_{b}, T_{l,}, \lambda$;

2. Compute upstream hydrograph $Q_{u}(t)$ by Eq. (1);

3. Compute upstream flow area $A_{u}(t)=\xi \cdot Q_{u}(t)^{\psi}$;

4. Compute downstream hydrograph $Q_{d}(t)$ by Eq. (8);

5. Compute downstream flow area $A_{d_{\text {model }}}(t)$, by the power function law

$$
A_{d_{\text {model }}}(t)=\lambda \cdot Q_{d}(t)^{\delta}=\lambda \cdot\left\{\left[Q_{u}\left(t-T_{l}\right)\right]+\left(\frac{L}{T_{l}}\right) \cdot\left[A_{d}(t)-\xi \cdot Q_{u}\left(t-T_{l}\right)^{\psi}\right]\right\}^{\delta}
$$

6. Compute the mean absolute error $(M A E)$ for the model produced downstream flow area and observed flow area, $X=A_{d}$, estimated as below:

$$
M A E=\frac{1}{N} \cdot \sum_{i=1}^{N}\left|A_{d_{\text {model }}}-A_{d_{o b s}}\right|
$$

7. Check the coefficient of determination, $R^{2}$, between $Q_{d_{\text {mod }}}(t)$ and $\left\{\frac{A_{d_{\text {obs }}}(t)}{A_{u_{\text {mod }}}\left(t-T_{l}\right)} \cdot Q_{u_{\text {mod }}}\left(t-T_{l}\right)\right\}$ of Eq. (9);

8. Continue minimizing the error for a threshold of $3 \%$, while trying to reach the optimal values of the parameters and coefficients in Step 1, by performing steps from 2) to 7).

9. Stop the iterations when the global minimum error is reached and the maximum coefficient of determination is obtained for Eq. (9). Therefore, the optimal values for the parameters and coefficients are obtained and $Q_{u}(t)$ and $Q_{d}(t)$ are assessed by Eqs. (1) and (8), respectively.

10. Refining of $Q_{u}(t)$ assessment by applying the procedure of Model 1 (step 1-7) assuming $Q_{d}(t)$ computed at step 9 of Model 2, $Q_{d_{E q}(B)}^{\text {model } 2}$, as "observed", so as to minimize the $M A E$ as:

$$
M A E=\frac{1}{N} \cdot \sum_{i=1}^{N}\left|Q_{d_{E q_{(B)}}^{M o l 1}}^{\text {Model2 }}-Q_{d_{E q_{(B)}}}^{\text {Mod }}\right|
$$

MODEL 3 - Stages recorded at channel ends:

1. Assign initial values for parameters $(x, y)$ of stage-discharge power law relationship at upstream end, i.e.;

$$
Q_{u}(\mathrm{t})=x \cdot A_{u}(t)^{y}
$$

2. Computation of $T_{l}$ by dimensionless stages recorded at channel ends following the procedure in Moramarco et al. (2005b).

3. Likewise Eq. (7), computation of downstream peak discharge by:

$$
Q_{d}\left(t_{p}\right)=\left[Q_{u}\left(t_{p}-T_{l}\right)\right]+\left(\frac{L}{T_{l}}\right) \cdot\left[A_{d}\left(t_{p}\right)-A_{u}\left(t_{p}-T_{l}\right)\right]
$$

where, $t_{p}$, represents the time to the peak level observed at downstream end. 
4. Computation of downstream baseflow discharge, $Q_{d}\left(t_{b}\right)$, surmising the same velocity at channel ends shifted by $T_{l}$ :

$$
Q_{d}\left(t_{b}\right)=\frac{A_{d}\left(t_{b}\right)}{A_{u}\left(t_{b}-T_{l}\right)} \cdot Q_{u}\left(t_{b}-T_{l}\right)
$$

where, $t_{b}$, is the time to the baseflow at downstream end;

5. Compute $\alpha_{R C M}$ and $\beta_{R C M}$ as below (Moramarco et al. 2005b);

$$
\begin{gathered}
\alpha_{R C M}=\left\{\frac{\left[Q_{d}\left(t_{p}\right)-Q_{d}\left(t_{b}\right)\right]}{\left[\frac{A_{d}\left(t_{p}\right)}{A_{u}\left(t_{p}-T_{l}\right)} \cdot Q_{u}\left(t_{p}-T_{l}\right)-\frac{A_{d}\left(t_{b}\right)}{A_{u}\left(t_{b}-T_{l}\right)} \cdot Q_{u}\left(t_{b}-T_{l}\right)\right]}\right\} \\
\beta_{R C M}=Q_{d}\left(t_{b}\right)-\left[a \cdot \frac{A_{d}\left(t_{b}\right)}{A_{u}\left(t_{b}-T_{l}\right)} \cdot Q_{u}\left(t_{b}-T_{l}\right)\right]
\end{gathered}
$$

6. Compute downstream hydrograph $Q_{d}(t)$ by Eq. (9).

7. Maximize the Nash-Sutcliffe coefficient, NS, considering the comparison between the observed flood volume as:

$$
V_{o b s}(t)=\left[A_{d}(t)-A_{u}\left(t-T_{l}\right)\right] \cdot L
$$

and the simulated one as:

$$
V_{\text {sim }}(t)=\left[Q_{d}(t)-Q_{u}\left(t-T_{l}\right)\right] \cdot T_{l}
$$

and NS is estimated as below:

$$
N S=1-\frac{\sum_{i=1}^{N}\left(V_{o b s, i}-V_{s i m, i}\right)^{2}}{\sum_{i=1}^{N}\left(V_{o b s, i}-\overline{V_{o b s}}\right)^{2}}
$$

where the bar indicates the average value.

8. Continue to maximize NS, while trying to reach the optimal values of the parameters and coefficients in Step 1, by performing steps from 2) to 7).

\section{Reverse Flood Routing}

\subsection{Watershed and Hydrologic Data}

The three developed models are applied to reverse flood routing in three river branches along the Tiber River in central Italy. Figure 2 shows the location of the selected hydrometric sections defining the investigated branches along with subtended drainage areas and, as can be seen, significant large intermediate basins are presents. It is worth noting that no information about rainfall, i.e., no rainfall-runoff analysis, is used for estimating the lateral flow and this is a considerable advantage respect to the need to apply a hydrological model. Table 1 
shows parameters used for each model, while Table 2 summarizes the main characteristics of the selected river reaches and as can be seen a large intermediate basin is present mainly for river reach 1 and 3 .

Each gauged section is equipped with a remote ultrasonic water level gauge, and velocity measurements are carried out by current meter. Several accurate flow measurements were available which allowed the estimation of reliable rating curve for each section (Moramarco et al. 2005b). The details can be obtained from Tayfur et al. (2007) as well.

Three flood events are considered for the analysis and Table 3 illustrates the main characteristics of their recorded at ends of equipped river reaches Santa Lucia-Ponte Nuovo, Ponte Nuovo-Monte Molino and Santa Lucia-Monte Molino. The observed wave travel time, is 6-8, 3-4 and 10-13 h for Santa Lucia-Ponte Nuovo reach, Ponte Nuovo-Monte Molino reach and Santa Lucia-Monte Molino reach, respectively (Barbetta et al. 2012; Tayfur et al. 2009). The selection of these events is based on the fact that they encompass normal flow up to the high flow referred to a return period of 100 years. Under the assumption of unknown upstream discharge hydrograph, as a first approximation the wave travel time can be estimated as the velocity associated at the downstream peak discharge divided by the reach length. Then, it was carried out an iterative process that has allowed to optimizing the value of $T_{l}$, respecting the linear condition of the relationship of the $R C M$ (Eq. 9). By way for example, Fig. 3 shows the linear relationship which is generally expected by the Rating Curve Model between $Q_{d}$ and $Q_{u}$, with very high $R^{2}$ values (Moramarco et al. 2005b; Barbetta et al. 2012).

In addition, two additional synthetic case studies are considered for a mere comparison with 1) a flood routing model based on Mike11 (DHI 2003) applied to the Tiber River in absence of lateral flow and where a detailed channel geometry is available and 2) a hydrologic model (Brocca et al. 2011) coupled with Mike 11 for estimation of discharge hydrograph at river sites in the Rio Grande basin, tributary of Tiber River. For the first case, a synthetic flood event is considered and routed along the reach Santa Lucia-Ponte Nuovo sketched by 160 topographical cross-sectional surveys. In this case, no lateral flow is considered. The main characteristics of flood event are shown in Table 3. For Rio Grande basin, the river reach considered is $12.5 \mathrm{~km}$ long represented by 40 topographical cross-sectional surveys. The discharge hydrograph at upstream end and the lateral flow of intermediate basin are obtained from the hydrological model by a rainfall-runoff transformation of a synthetic rainfall referred to a return period of 50 years. Mike11 is applied to route the upstream inflow along the lateral flow. Characteristic of upstream inflow are given in Table 3. It is worth stressing that these two case studies are addressed only to verify the capability of the proposed procedure in comparison with hydraulic models working in the same context and using the simulated discharge by MIKE 11 as a benchmark.

\subsection{GA Model Implementation}

The GA is applied to obtain the optimal values of the parameters and coefficients of models in Table 1 by minimizing the mean absolute error $(M A E)$ or by maximizing the Nash-Sutcliffe coefficient $(N S)$ such as described in the procedure according the configuration considered.

\subsection{Model 1 - Coefficients and Parameters}

Initially, taking observed downstream hydrograph into account, random values were assigned for peak rate $Q_{p_{u}}$, for time to peak $t_{p_{u}}$ and for baseflow $Q_{b}$. Initial values of 1.75 for $\xi$ and 0.75 


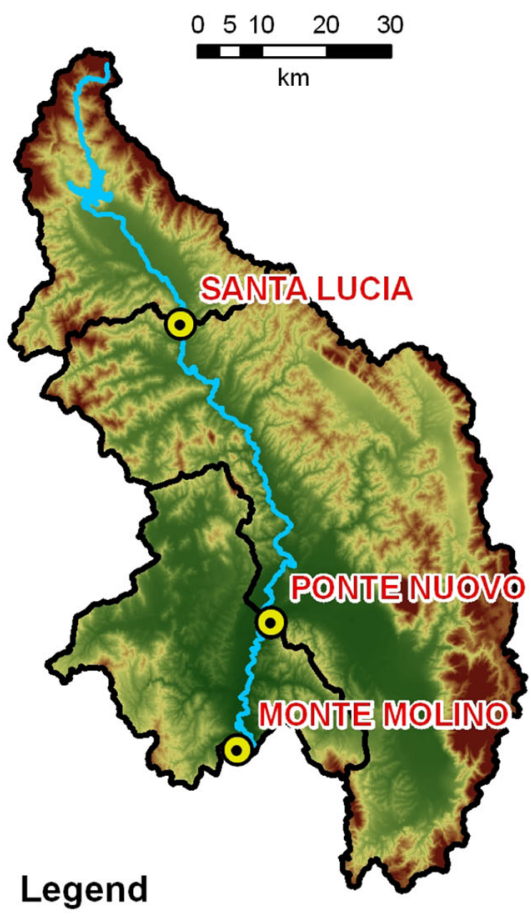

- Gauging sections

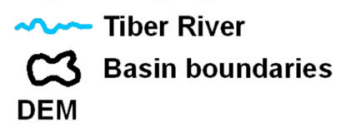

Elevation

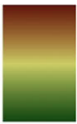

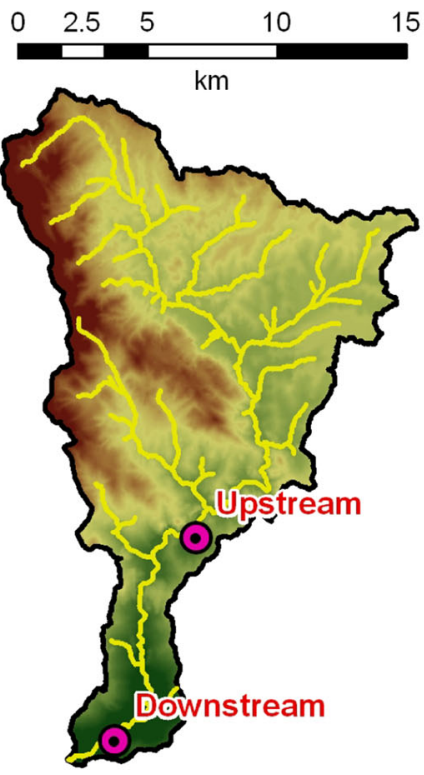

Legend

- Rio Grande sections

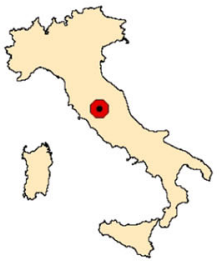

Stream networks

DEM

Elevation

High : 994

m a.s.I.

Low : 52

Fig. 2 Tiber River basin and gauging sections (left) and Rio Grande basin (right)

Table 2 Main geomorphological characteristics of Tiber River and Rio Grande reaches

\begin{tabular}{|c|c|c|c|c|c|}
\hline Tiber reach & $\begin{array}{l}\text { Bounded } \\
\text { sections }\end{array}$ & $\begin{array}{l}\text { Drainage } \\
\text { area }\left(\mathrm{km}^{2}\right)\end{array}$ & $\begin{array}{l}\text { Reach } \\
\text { length }(\mathrm{km})\end{array}$ & Mean slope & $\begin{array}{l}\text { Mean } \\
\text { width (m) }\end{array}$ \\
\hline \multirow[t]{2}{*}{1} & Santa Lucia & 935 & 65.00 & 0.0014 & 45 \\
\hline & Ponte Nuovo & 4145 & & & \\
\hline \multirow[t]{2}{*}{2} & Ponte Nuovo & 4145 & 30.83 & 0.0009 & 50 \\
\hline & Monte Molino & 5280 & & & \\
\hline \multirow[t]{2}{*}{3} & Santa Lucia & 935 & 95.83 & 0.0013 & 47 \\
\hline & Monte Molino & 5280 & & & \\
\hline Rio Grande reach & $\begin{array}{l}\text { Bounded } \\
\text { Sections }\end{array}$ & $\begin{array}{l}\text { Drainage } \\
\quad \text { Area }\left(\mathrm{km}^{2}\right)\end{array}$ & $\begin{array}{l}\text { Reach } \\
\text { Length }(\mathrm{km})\end{array}$ & Mean Slope & $\begin{array}{l}\text { Mean } \\
\text { Width (m) }\end{array}$ \\
\hline \multirow[t]{2}{*}{1} & Upstream & 150 & 12.5 & - & - \\
\hline & Downstream & 190 & & & \\
\hline
\end{tabular}


Table 3 Main characteristics of flood events observed and based on MIKE 11 at all stations $\left(Q_{b}\right.$ : baseflow, $Q_{p}$ : peak flow, $\mathrm{V}$ : volume, $\mathrm{T}_{1}$ : wave travel time)

\begin{tabular}{|c|c|c|c|c|c|c|c|}
\hline \multirow[t]{2}{*}{ Date } & \multicolumn{3}{|c|}{ Santa lucia station } & \multicolumn{3}{|c|}{ Ponte nuovo station } & \multirow[t]{2}{*}{$\mathrm{T}_{1}(\mathrm{~h})$} \\
\hline & $\mathrm{Q}_{\mathrm{b}}\left(\mathrm{m}^{3} / \mathrm{s}\right)$ & $\mathrm{Q}_{\mathrm{p}}\left(\mathrm{m}^{3} / \mathrm{s}\right)$ & $\mathrm{V}\left(10^{6} \mathrm{~m}^{3}\right)$ & $\mathrm{Q}_{\mathrm{b}}\left(\mathrm{m}^{3} / \mathrm{s}\right)$ & $\mathrm{Q}_{\mathrm{p}}\left(\mathrm{m}^{3} / \mathrm{s}\right)$ & $\mathrm{V}\left(10^{6} \mathrm{~m}^{3}\right)$ & \\
\hline November 05 & 123.080 & 403.030 & 39.971 & 64.570 & 1109.760 & 151.830 & 6.74 \\
\hline December 08 & 13.950 & 328.320 & 36.106 & 94.840 & 902.760 & 145.680 & 6.90 \\
\hline March 11 & 52.340 & 151.730 & 19.246 & 111.000 & 396.330 & 51.750 & 6.65 \\
\hline Date & \multicolumn{3}{|c|}{ Ponte Nuovo Station } & \multicolumn{3}{|c|}{ Monte Molino Station } & $\mathrm{T}_{1}(\mathrm{~h})$ \\
\hline November 05 & 64.570 & 1109.760 & 151.832 & 58.450 & 1192.620 & 185.400 & 3.00 \\
\hline December 08 & 94.840 & 902.760 & 145.680 & 101.310 & 1084.200 & 219.060 & 2.98 \\
\hline March 11 & 111.000 & 396.330 & 51.749 & 93.650 & 574.590 & 75.620 & 3.14 \\
\hline Date & \multicolumn{3}{|c|}{ Santa Lucia Station } & \multicolumn{3}{|c|}{ Monte Molino Station } & $\mathrm{T}_{1}(\mathrm{~h})$ \\
\hline November 05 & 123.080 & 403.030 & 39.971 & 58.450 & 1192.620 & 185.400 & 9.34 \\
\hline December 08 & 13.950 & 328.320 & 36.106 & 101.310 & 1084.200 & 219.060 & 9.27 \\
\hline March 11 & 52.340 & 151.730 & 19.246 & 93.650 & 574.590 & 75.620 & 9.76 \\
\hline River reach & \multicolumn{3}{|l|}{ Upstream } & \multicolumn{3}{|c|}{ Downstream } & $\mathrm{T}_{1}(\mathrm{~h})$ \\
\hline SL-PN (MIKE 11) & 5 & 1399.691 & 86.957 & 5 & 1341.363 & 86.605 & 6.62 \\
\hline Rio Grande (MIKE 11) & 3 & 161.087 & 3.331 & 4 & 175.957 & 3.852 & 1.24 \\
\hline
\end{tabular}

for $\psi$ were assigned. These two values are determined assuming that the normalized downstream stage hydrograph holds for upstream end as well. As model does iterations while reaching a global error, the values of parameters and coefficients are updated at each iteration. Thus, the effect of initially assigned values diminishes as the number of iterations increases.

The range of variability for parameters and coefficients of first model are settled as in the sequel:

$$
\begin{cases}Q_{p_{u}}=0.7 \cdot \frac{A_{\text {drainage }_{u}}}{A_{\text {drainage }_{d}}} \cdot Q_{p_{d}} & \text { (minimum value }) \\ Q_{p_{u}}=2.5 \cdot \frac{A_{\text {drainage }_{u}}}{A_{\text {drainage }_{d}}} \cdot Q_{p_{d}} & (\text { minimum value })\end{cases}
$$

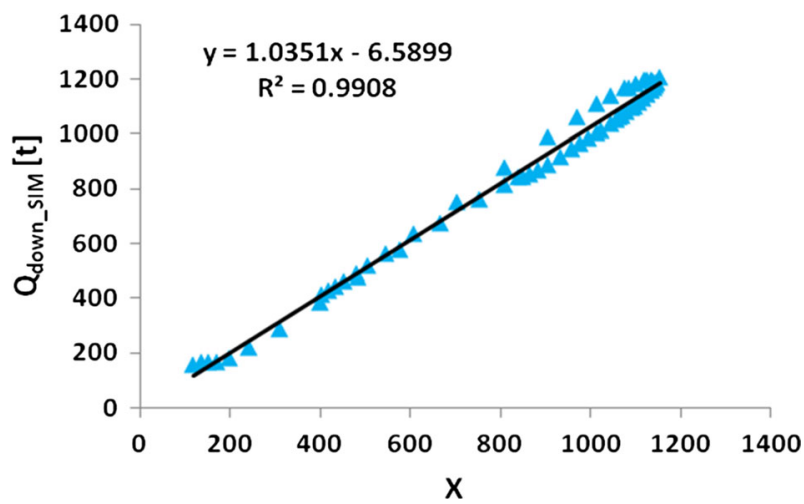

Fig. 3 Linear relationship of Rating Curve Model, where: $X=\left\{\frac{A_{d}(t)}{A_{u}\left(t-T_{1}\right)} \cdot Q_{u}\left(t-T_{1}\right)\right\}$ 
where, $A_{\text {drainage }}$, represent the intermediate drainage area of the river reach.

$$
\begin{gathered}
\left\{\begin{array}{cc}
t_{p_{u}}=t_{p_{d}}-T_{l} \quad(\text { minimum value }) \\
t_{p_{u}}=t_{p_{d}}-3 T_{l} \quad(\text { minimum value })
\end{array}\right. \\
\left\{\begin{array}{l}
Q_{b_{u}}=0.5 \cdot \frac{\text { Adrainage }_{u}}{\text { Adrainage }_{d}} \cdot Q_{d}(t=1 h) \quad(\text { minimum value }) \\
Q_{b_{u}}=1.5 \cdot \frac{\text { Adrainage }_{u}}{\text { Adrainage }_{d}} \cdot Q_{d}(t=1 h) \quad(\text { minimum value })
\end{array}\right.
\end{gathered}
$$

$\xi=[1-10]$ and $\psi=[0-5]$ where, for $Q_{p_{u}}, t_{p_{u}}$ and $Q_{b}$ is reported the minimum and maximum value, while for $\xi$ and $\psi$ the range is indicated between brackets.

In particular, it was found that the optimal $T_{l}$ is the one for which the maximum coefficient of determination, $R^{2}$, is obtained between the two quantities $Q_{d}(t)$ and $\left\{\frac{A_{d}(t)}{A_{u}\left(t-T_{l}\right)} Q_{u}\left(t-T_{l}\right)\right\}$.

\subsection{Model 2 - Coefficients and Parameters}

Initially, taking observed stages recorded at downstream end into account, random values were assigned for peak rate $Q_{p_{u}}$, for time to peak $t_{p_{u}}$ and for baseflow $Q_{b}$. Initial values of 1.75 for $\xi, 0.75$ for $\psi, 2.5$ for $\lambda$ and 2.5 for $\delta$ were assigned. The range of variability for parameters and coefficients of second model are the same of Model 1, while for

$$
\lambda=[0.10] \text { and } \delta=[0-10]
$$

\subsection{MODEL 3 - Parameters}

Initially, taking observed stages recorded at channel ends into account, random values were assigned; in particular, values of 2 and 1.25 were assigned initially for $x$ and $y$, respectively.

The range of variability for coefficients of third model is:

$$
x=[0.5-3] \text { and } y=[0.5-1.5]
$$

During GA iterations, the optimal values of parameters were searched within the range which is decided by taking into account the known quantities, the drainage area and the wave travel time of the river reach. With regard to the search ranges assigned to the parameters, we benefited from existing knowledge of the size of drainage areas, reach lengths, travel times, etc.

The GA employed 100 chromosomes in the initial gene pool, $80 \%$ cross-over rate and $4 \%$ mutation rate. Tolerance limit (the difference of error between successive iterations) of 0.001 was employed. This was generally accomplished in between 1000 and 5000 iterations. The evolver GA solver for Microsoft Excel (Palisade Corporation 2013) package program was employed in this study. The algorithm employs the Recipe Solving Method to minimize the objective function under specified constraints (Palisade Corporation 2013). It takes a very short CPU time, in the order of couple of 
minutes, to run the program for thousands of iterations with $100 \mathrm{~s}$ chromosomes in the gene pool.

\section{Results}

\subsection{Model 1 - Stages and Discharges Recorded at Downstream End}

\subsubsection{Santa Lucia - Ponte Nuovo River Reach}

Tables 4 summarizes the optimal values of parameters and coefficients for reverse routing the flood hydrographs. Figure 4 shows the reverse flood routing simulation for the event November 2005 in the Santa Lucia-Ponte Nuovo river reach. As can be seen, the discharge hydrograph simulated at both channel ends are quite well reproduced. Inspecting Table 5 that depicts the performance measures for all events, the value of Nash-Sutcliffe (NS) at upstream end are higher for the event November 2005 with value greater than 0.95 , while for the event March 2011 NS, is found lower and equal to 0.79. For the event March 2011, RMSE is found lower than the others ones, not exceeding $13.3 \mathrm{~m}^{3} \mathrm{~s}^{-1}$ at upstream end. In terms of error in time to peak at upstream end, it is found not exceeding $5 \mathrm{~h}$, while, in terms of error to peak discharge, it is found not exceeding $11 \%$. The reason about differences of performance may be found in the assumption of celerity as depicted by Eqs. (3) and (4) which is surmised constant as $L / T_{l}$. The more celerity is far from the actual one, more the performance drops down. At downstream end, the discharge hydrograph by Eq. (8) is found good as can be inferred by Table 5. At the end, for upstream discharge assessment results can be considered quite satisfactory.

\subsubsection{Ponte Nuovo - Monte Molino River Reach}

The events in terms of simulated hydrograph are performed fairly well by the reverse routing as shown in Fig. 4 (only the event of December 2008), even though the shape is not perfectly reproduced and better performances are obtained for the event November 2005. Tables 4 summarizes the optimal values of parameters and coefficients for reverse routing the flood hydrographs. Inspecting Table 5 that depicts the performance measures for all events, the value of Nash-Sutcliffe (NS) at upstream end are higher for the event November 2005 with values greater than 0.9 , while for the event December 2008 and March 2011 NS, is equal to 0.61 and 0.63 , respectively. For the event March 2011, RMSE is found lower than the others ones, not exceeding $49.4 \mathrm{~m}^{3} \mathrm{~s}^{-1}$ at upstream end and this can be justified considering the lower magnitude of the flood. In terms of error in time to peak at upstream end, it is found not exceeding $3 \mathrm{~h}$, while, in terms of error to peak discharge, it is found not exceeding $21 \%$. Even in this case, downstream discharge hydrograph simulated by Eq. (8) is satisfactorily reproduced.

\subsubsection{Santa Lucia - Monte Molino River Reach}

Figure 4 shows the comparison between observed and computed discharge at channel ends for the event of March 2011. As can be seen results are fairly good in terms of 
Table 4 Optimal values of parameters and coefficients for reverse routing flood hydrographs for Model 1

\begin{tabular}{lccccccc}
\hline River reach & \multicolumn{7}{l}{ Parameters and coefficients } \\
\cline { 2 - 7 } & $\mathrm{Q}_{\text {p_upstream }}\left(\mathrm{m}^{3} / \mathrm{s}\right)$ & $\mathrm{t}_{\mathrm{p} \_ \text {upstream }}(\mathrm{h})$ & $\gamma(-)$ & $\xi(-)$ & $\psi(-)$ & $\mathrm{T}_{1}(\mathrm{~h})$ & $\mathrm{Q}_{\mathrm{b}}\left(\mathrm{m}^{3} / \mathrm{s}\right)$ \\
\hline SL-PN NOV2005 & 433.832 & 11.694 & 1.600 & 2.325 & 0.738 & 7 & 12.508 \\
PN-MM NOV2005 & 1040.184 & 25.000 & 1.450 & 1.276 & 0.832 & 3 & 60.000 \\
SL-MM NOV2005 & 355.880 & 14.924 & 1.500 & 2.076 & 0.732 & 10 & 25.000 \\
SL-PN DEC2008 & 273.268 & 20.062 & 1.400 & 1.026 & 0.855 & 7 & 25.311 \\
PN-MM DEC2008 & 793.871 & 29.005 & 1.600 & 2.668 & 0.709 & 4 & 77.251 \\
SL-MM DEC2008 & 272.024 & 22.000 & 1.500 & 9.518 & 0.337 & 12 & 29.032 \\
SL-PN MAR2011 & 110.707 & 15.350 & 1.400 & 2.166 & 0.680 & 7 & 39.955 \\
PN-MM MAR2011 & 250.030 & 24.063 & 1.400 & 5.813 & 0.569 & 3 & 64.083 \\
SL-MM MAR2011 & 145.881 & 16.862 & 1.400 & 2.411 & 0.649 & 12 & 17.738 \\
\hline
\end{tabular}

hydrograph shape as well. Tables 4 summarizes the optimal values of parameters and coefficients for reverse routing the flood hydrographs. Inspecting Table 5 showing the performance measures for all events, the value of Nash-Sutcliffe $(N S)$ are higher for the event November 2005 with values equal to 0.89, while for the event March 2011 $N S$, is equal to 0.44 . For the event March 2011, RMSE is found lower than the others ones, not exceeding $22 \mathrm{~m}^{3} \mathrm{~s}^{-1}$. In terms of absolute error in time to peak at upstream end, it is found on average almost $4 \mathrm{~h}$, while, in terms of error to peak discharge, it is found not exceeding $9 \%$.
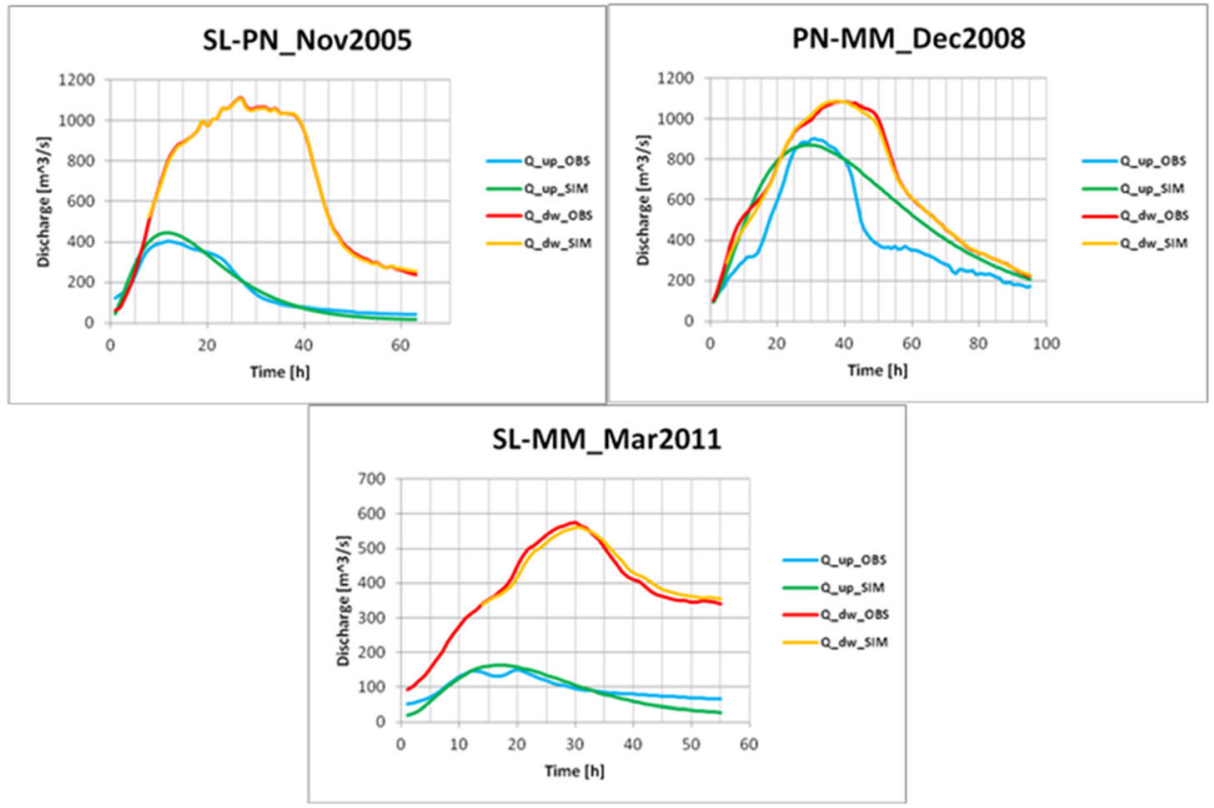

Fig. 4 Generated upstream and downstream hydrographs for simulated flood events in the Santa Lucia-Ponte Nuovo (Nov2005), Ponte Nuovo-Monte Molino (Dec2008) and Santa Lucia-Monte Molino (Mar2011) river reach by Model 1 


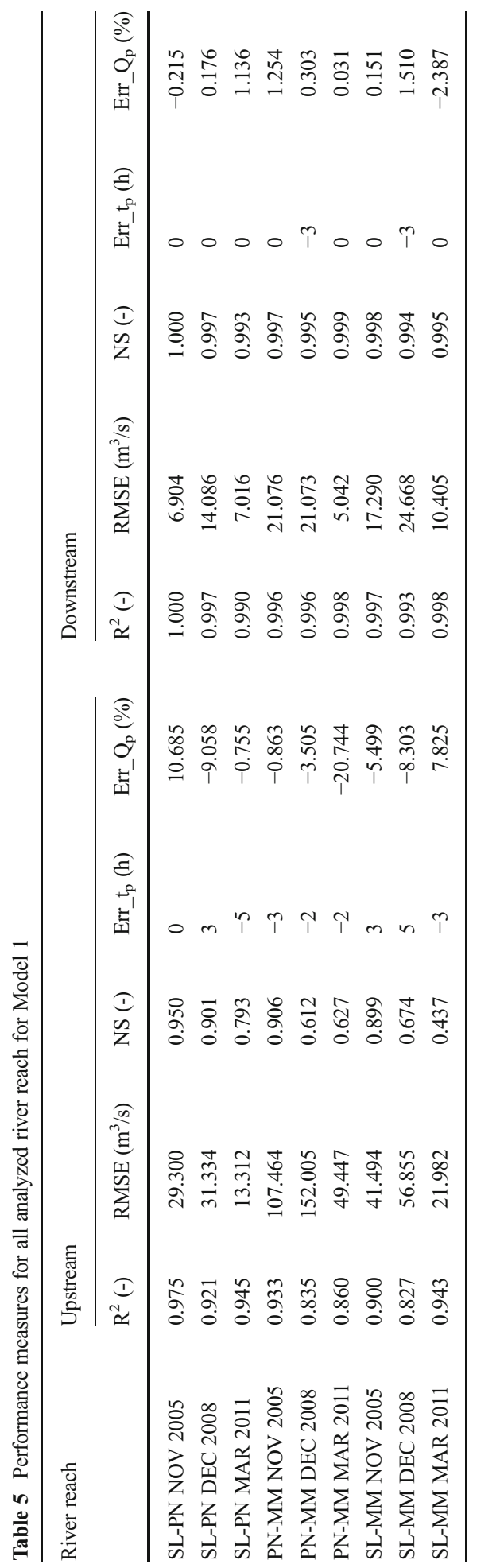




\section{Model 2 - Stages Recorded at Downstream End}

\subsection{Santa Lucia - Ponte Nuovo River Reach}

Figure 5a) depicts the comparison between the rating curve estimated at Ponte Nuovo site (downstream) by considering all events, and the observed one. As it can be seen a good correspondence is found. Tables 6 summarizes the optimal values of parameters and coefficients for reverse routing the flood hydrographs. The discharge hydrograph simulated at both channel ends are well reproduced, even though better performances are obtained for the event March 2011 as shown in Table 7. Nash-Sutcliffe (NS) values are higher for the event November 2005 with value greater than 0.91, while for the event March 2011 NS, is found equal to 0.8 and 0.96 for upstream and downstream channel end, respectively. For the event March 2011, RMSE is found lower than the others ones, not exceeding $14 \mathrm{~m}^{3} \mathrm{~s}^{-1}$ at upstream end. In terms of error in time to peak at channel ends and to peak discharge, it is found not exceeding $4 \mathrm{~h}$ and $26 \%$, respectively. Lower performances can be ascribed to the assumption of celerity as well as the lateral flow considered uniform along the river reach.

\subsection{Ponte Nuovo - Monte Molino River Reach}

For the three events, discharge hydrographs are successfully performed at channel ends by the reverse flood routing model. The goodness of the simulated discharges can be inferred from the comparison at downstream end of simulated and observed rating curves as shown in Fig. 5b). Tables 6 summarizes the optimal values of parameters and coefficients for reverse

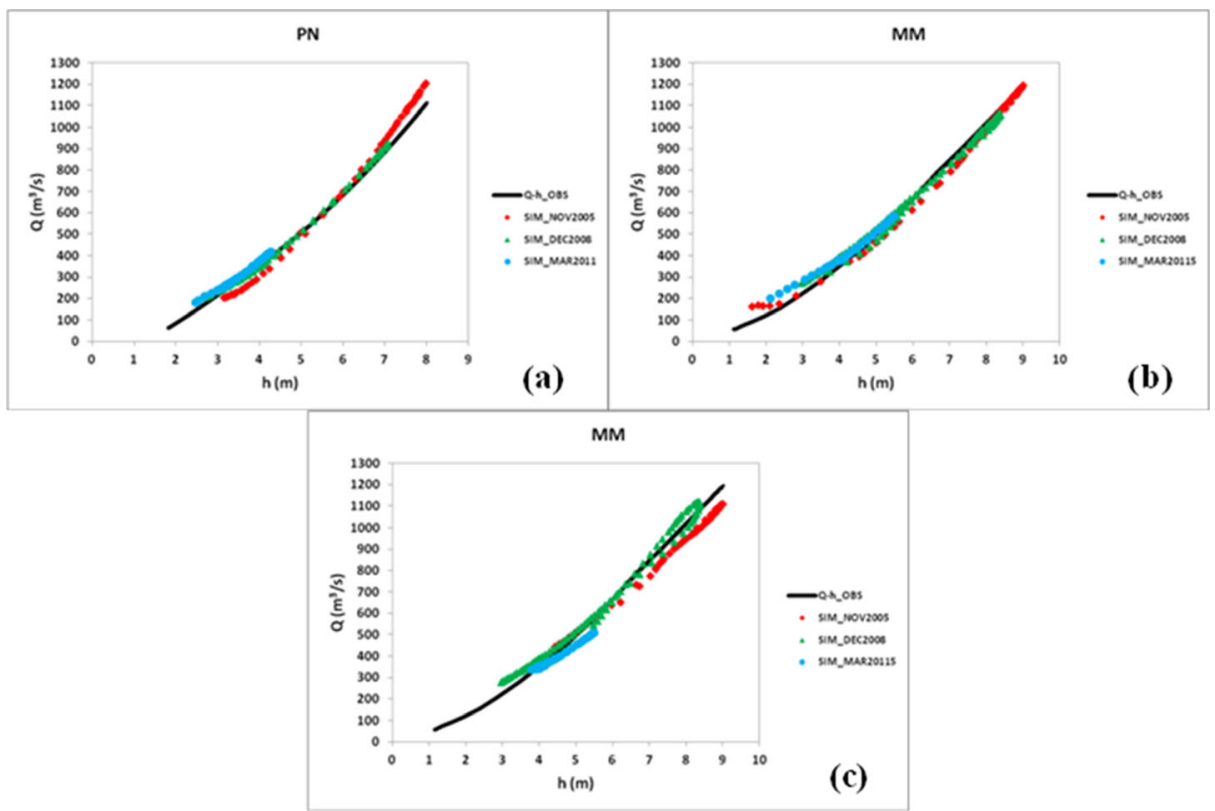

Fig. 5 Rating Curve for all analyzed flood events at Ponte Nuovo and Monte Molino sections by Model 2. a Santa Lucia-Ponte Nuovo river reach; b Ponte Nuovo-Monte Molino river reach; c Santa Lucia-Monte Molino river reach 
routing the flood hydrographs. Table 7 illustrates the performance measures for all events, and as can be seen the value of Nash-Sutcliffe (NS) are higher for the event March 2011 with values greater than 0.89, while for the event November 2005 and December $2008 \mathrm{NS}$, is equal to 0.75 and 0.6, respectively. For the event March 2011, RMSE is found lower than the others ones, not exceeding $28 \mathrm{~m}^{3} \mathrm{~s}^{-1}$ at upstream end. In terms of error in time to peak and peak discharge at channel ends, it is found not exceeding $2 \mathrm{~h}$ and $10 \%$, respectively.

\subsection{Santa Lucia - Monte Molino River Reach}

The discharge hydrograph simulated at both channel ends are well reproduced, even though better performances are obtained for the event November 2005. Tables 6 summarizes the optimal values of parameters and coefficients for reverse routing the flood hydrographs. Table 7 details the performance measures for all events showing that the value of NashSutcliffe (NS) is higher for the event November 2005 with values equal to 0.9 , while for the event March 2011 NS, is equal to 0.34. For the event March 2011, RMSE is found lower than the others ones, not exceeding $24 \mathrm{~m}^{3} \mathrm{~s}^{-1}$ at upstream end. In terms of error in time to peak at upstream end, it is found not exceeding $3 \mathrm{~h}$, while, in terms of error to peak discharge, it is found not exceeding $30 \%$ (at downstream end is lower than $12 \%$ ). Figure $5 \mathrm{c}$ ) shows the reliability of the model by the comparison of observed and computed rating curve at Monte Molino site for all investigated flood events.

\subsection{Model 3 - Stages Recorded at Channel Ends}

\subsubsection{Santa Lucia - Ponte Nuovo River Reach}

The discharge hydrograph simulated at both channel ends are well reproduced, even though better performances are obtained for the event November 2005. Tables 8 summarizes the optimal values of parameters and coefficients for reverse routing the flood hydrographs. It is worth noting that the estimation of wave travel time, $T_{l}$, is fundamental for a good performance of model and for that is advisable to use the dimensionless stages as proposed by Moramarco et al. (2005b). The accuracy of the model is proved by Table 9 that depicts the performance

Table 6 Optimal values of parameters and coefficients for reverse routing flood hydrographs for Model 2

\begin{tabular}{lllllllllll}
\hline River reach & \multicolumn{1}{l}{ Parameters and coefficients } \\
\cline { 2 - 10 } & $\mathrm{Q}_{\mathrm{p} \_ \text {upstream }}\left(\mathrm{m}^{3} / \mathrm{s}\right)$ & $\mathrm{t}_{\mathrm{p} \_ \text {upstream }}(\mathrm{h})$ & $\gamma(-)$ & $\xi(-)$ & $\psi(-)$ & $\mathrm{T}_{\mathrm{L}}(\mathrm{h})$ & $\mathrm{Q}_{\mathrm{b}}\left(\mathrm{m}^{3} / \mathrm{s}\right)$ & $\lambda(-)$ & $\delta(-)$ \\
\hline SL-PN NOV2005 & 353.432 & 14.306 & 1.600 & 7.594 & 0.544 & 6 & 22.678 & 0.709 & 1.218 \\
PN-MM NOV2005 & 1100.096 & 27.869 & 1.450 & 1.482 & 0.813 & 3 & 44.684 & 0.521 & 1.257 \\
SL-MM NOV2005 & 428.890 & 11.173 & 1.500 & 1.453 & 0.800 & 11 & 12.394 & 2.797 & 0.971 \\
SL-PN DEC2008 & 217.003 & 20.673 & 1.400 & 1.000 & 0.846 & 7 & 27.880 & 2.211 & 1.020 \\
PN-MM DEC2008 & 752.036 & 30.502 & 1.600 & 1.035 & 0.853 & 4 & 86.476 & 1.796 & 1.053 \\
SL-MM DEC2008 & 217.534 & 19.229 & 1.500 & 2.078 & 0.423 & 12 & 14.618 & 1.630 & 1.070 \\
SL-PN MAR2011 & 120.087 & 16.440 & 1.400 & 1.311 & 0.763 & 7 & 38.270 & 0.244 & 1.493 \\
PN-MM MAR2011 & 286.044 & 25.811 & 1.400 & 1.657 & 0.783 & 3 & 72.836 & 1.750 & 1.052 \\
SL-MM MAR2011 & 122.473 & 17.386 & 1.400 & 1.914 & 0.753 & 12 & 15.939 & 3.283 & 0.911 \\
\hline
\end{tabular}




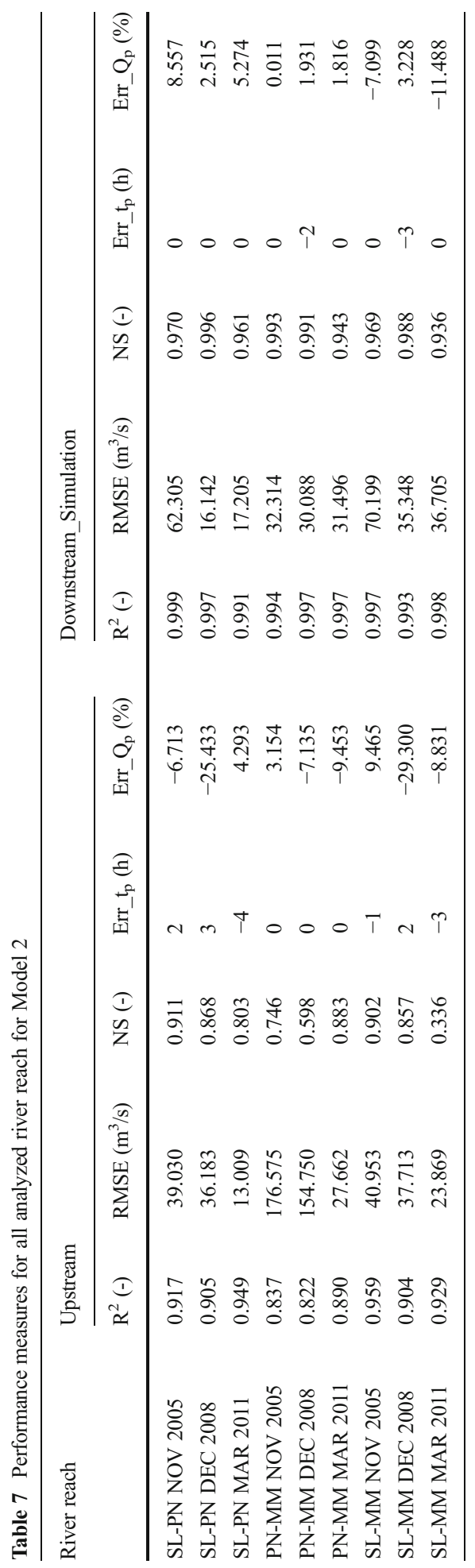


measures for all events and, the value of Nash-Sutcliffe (NS) for all the event is found close to

1. The good performances for Model 3 can be ascribed because $T_{l}$ is estimated not following an iterative approach but through the recorded stages as proposed by Moramarco et al. (2005b). For the event March 2011, RMSE is lower than the others ones, not exceeding 10.3 $\mathrm{m}^{3} \mathrm{~s}^{-1}$ and $24 \mathrm{~m}^{3} \mathrm{~s}^{-1}$, at upstream end and downstream end, respectively. The error in time to peak and peak discharge at channel ends, do not exceed 1 and $10 \%$, respectively. Figure 6 (upper panels) shows the rating curves estimated at channel ends for the three events and they well compare the observed ones.

\subsubsection{Ponte Nuovo - Monte Molino River Reach}

The upstream hydrograph is successfully performed by the reverse flood routing model. Tables 8 details the optimal values of parameters and coefficients for reverse flood routing. Moreover, as can be seen in Table 9, the performance measures of discharge hydrograph simulated at channel ends are overall quite satisfactory with a Nash-Sutcliffe (NS) close to 1 for all events. For the event December 2008, RMSE is found lower than the others ones, not exceeding $14 \mathrm{~m}^{3} \mathrm{~s}^{-1}$ at upstream end. In terms of error in time to peak and peak discharge at channel ends, it is found not exceeding $2 \mathrm{~h}$ and $7 \%$, respectively. Figure 6 (middle panels) shows even for this river reach the good performance in terms of rating curve estimation at channel ends.

\subsubsection{Santa Lucia - Monte Molino River Reach}

The discharge hydrograph simulated at both channel ends are well reproduced, even though better performances are obtained for the event December 2008. Tables 8 summarizes the optimal values of parameters and coefficients for reverse routing the flood hydrographs. Table 9 shows the performance measures for all events, the value of Nash-Sutcliffe (NS) is close to 1 for all analyzed events. For the event March 2011, RMSE is found lower than the others ones, not exceeding $6.1 \mathrm{~m}^{3} \mathrm{~s}^{-1}$ at upstream end. In terms of error in time to peak and peak discharge at channel ends, it is found not exceeding $1 \mathrm{~h}$, and $13 \%$, respectively. Figure 6 (lower panels) shows even for this river reach the good performance in terms of rating curve estimation at channel ends.

Table 8 Optimal values of parameters and coefficients for reverse routing flood hydrographs for Model 3

\begin{tabular}{|c|c|c|c|c|}
\hline \multirow[t]{2}{*}{ River reach } & \multicolumn{4}{|c|}{ Parameters and coefficients } \\
\hline & $\alpha_{\mathrm{RCM}}$ & $\beta_{\mathrm{RCM}}$ & X (-) & Y (-) \\
\hline SL-PN NOV2005 & 0.999 & 0.135 & 2.406 & 1.000 \\
\hline PN-MM NOV2005 & 0.984 & 1.702 & 1.284 & 1.106 \\
\hline SL-MM NOV2005 & 1.000 & 0.004 & 2.420 & 1.000 \\
\hline SL-PN DEC2008 & 0.998 & 0.228 & 2.262 & 1.000 \\
\hline PN-MM DEC2008 & 0.971 & 4.879 & 1.635 & 1.070 \\
\hline SL-MM DEC2008 & 1.038 & -7.104 & 2.429 & 0.991 \\
\hline SL-PN MAR2011 & 1.068 & -9.481 & 2.604 & 0.950 \\
\hline PN-MM MAR2011 & 0.922 & 13.297 & 1.309 & 1.133 \\
\hline SL-MM MAR2011 & 0.998 & 0.383 & 2.043 & 1.001 \\
\hline
\end{tabular}




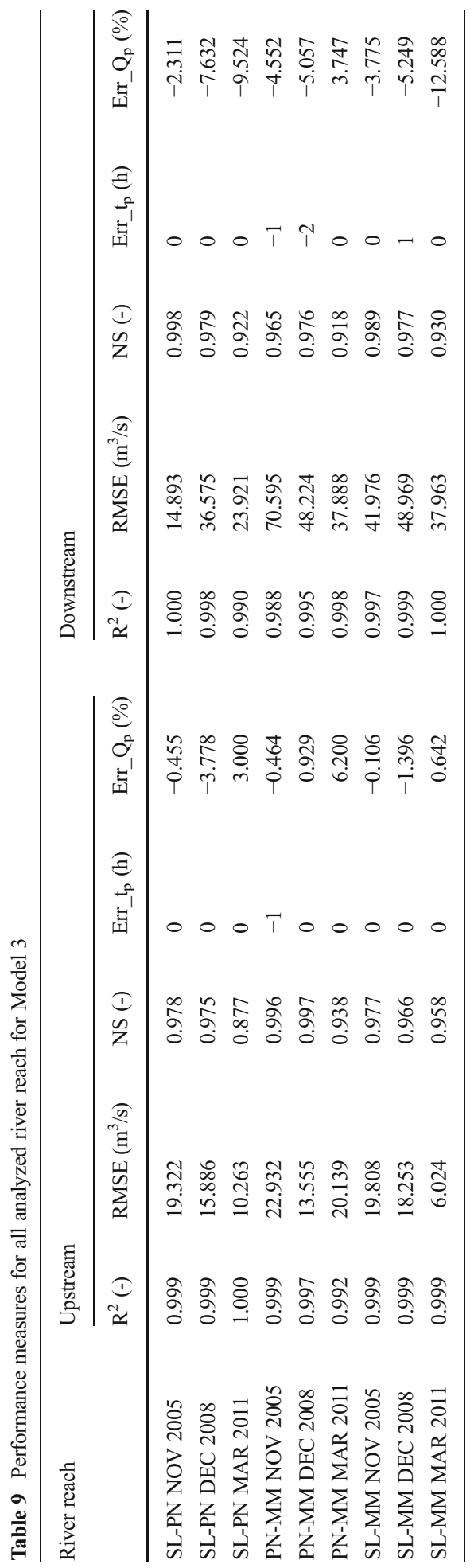



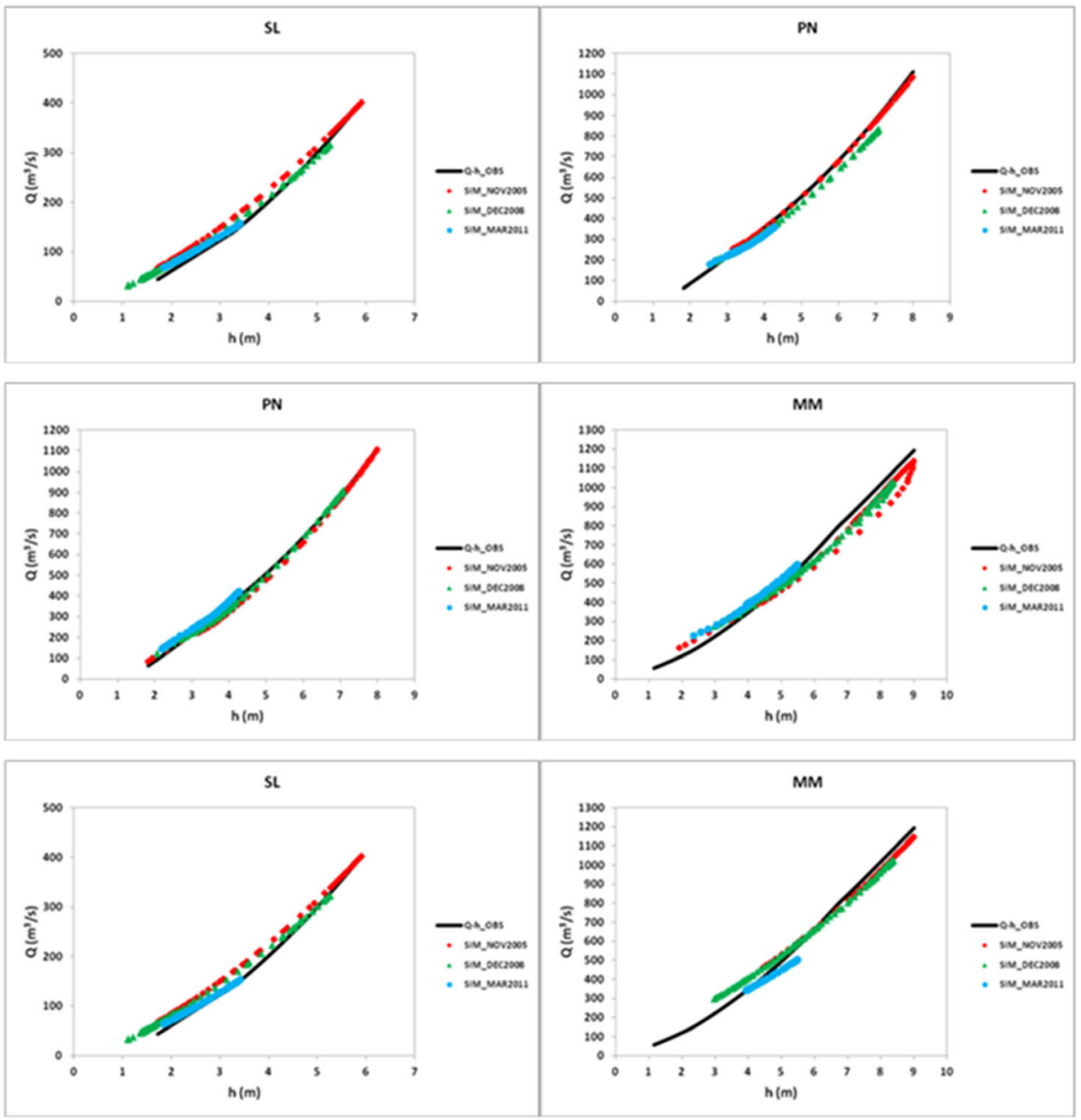

Fig. 6 Rating Curve for all analyzed flood events at Santa Lucia, Ponte Nuovo and Monte Molino sections by Model 3. Santa Lucia-Ponte Nuovo river reach (upper panels); Ponte Nuovo-Monte Molino river reach (middle panels); Santa Lucia-Monte Molino river reach (lower panels)

Based on results of the three different configurations as such depicted by Model 1, 2 and 3 and considering that no information is used for upstream end (except Model 3, where it was employed the Rating Curve Model using stages recorded at channel ends), the capability of reverse flow routing approaches can be considered quite good also for larger river reach with a significant intermediate drainage area. In addition, the performance measures in Table 9 compared with Table 5 and 7, shed light that the lower magnitude of flood, the lower performances are for all models. This is of paramount importance if extreme events are of interest from a hydrological point of view, considering that only stage hydrograph and discharge observed at downstream end is suffice for obtaining satisfactory results in terms of reverse flow routing at upstream end. For ordinary floods, the lower performance might be associated to the assumption on wave travel time that depending on downstream peak discharge it might be affected by a more significant velocity gradient along the river reach than 
the one occurring for a high flood. However, additional investigation is necessary to show it and this would be the object of future analysis.

\subsubsection{Synthetic Test - Comparison with Hydraulic and Hydrologic Model}

For a mere comparison with a hydraulic and hydrologic model, two river reaches are selected. The aim of this section is just to verify the performance of the three models with respect to existing hydrograph routing software like MIKE11 which is also coupled with a hydrologic model for the second river reach where a synthetic rainfall hyetograph is used for the whole basin. It is stressed that the same comparison is not possible for the previous investigated cases, because of lack of information about the contribution of the large intermediate drainage basin. For the flow routing a Manning roughness value of $0.04 \mathrm{~m}^{-1 / 3} \mathrm{~s}$ is used for both investigated channels.

\subsubsection{Santa Lucia - Ponte Nuovo River Reach}

The three models are applied for estimating the discharge hydrographs at channel ends using as a benchmark the hydraulic information coming from the hydraulic model MIKE11 that has routed a synthetic upstream inflow in absence of lateral flow. Specifically, the discharge and stage hydrograph simulated by MIKE11 at channel ends are used to initialize the three models. In this way, the models effectiveness is identified by the performance measures shown in Table 10. As can be seen by Fig. 7 (left), the discharge hydrograph simulated by MIKE11 using the complete geometry of the Tiber river reach are reproduced fairly well by the three reverse models with a maximum error in peak discharge of $13 \%$ at upstream end for the Model 2 and of $14 \%$ at downstream end for the Model 3. Indeed, Model 3 performs poorer than the other models to simulate the downstream discharge hydrograph as shown in Fig. 7. Indeed, the error in peak discharge is equal to $14 \%$, yet the shape of both hydrographs are well simulated with a NS greater than 0.95 . Model 1 and 2 simulate very well the downstream discharge hydrograph, while the upstream one is not so accurate as can be inferred by the NS values equal to 0.74 for Model 1 and 0.71 for Model 2. This latter result is expected considering that for Model 1 and Model 2 no information is given in terms of flow stage at upstream end. Nevertheless, considering the poor data (absence of channel topography and rainfall) used to estimate the hydraulic information at channel ends, all models can be considered satisfactory considering that the benchmark for the validation is obtained using all information available in terms of channel geometry identified by 160 topographical river crosssection surveys.

Table 10 Performance measures for Santa Lucia-Ponte Nuovo river reach for Model 1-2-3

\begin{tabular}{|c|c|c|c|c|c|c|c|c|c|c|}
\hline \multirow[t]{2}{*}{ River reach } & \multicolumn{5}{|c|}{ Upstream } & \multicolumn{5}{|c|}{ Downstream } \\
\hline & $\mathrm{R}^{2}(-)$ & $\begin{array}{l}\text { RMSE } \\
\left(\mathrm{m}^{3} / \mathrm{s}\right)\end{array}$ & NS (-) & $\begin{array}{l}\text { Err_t } t_{p} \\
\text { (h) }\end{array}$ & $\begin{array}{l}\text { Err_Q } Q_{p} \\
(\%)\end{array}$ & $\mathrm{R}^{2}(-)$ & $\begin{array}{l}\text { RMSE } \\
\left(\mathrm{m}^{3} / \mathrm{s}\right)\end{array}$ & NS (-) & $\begin{array}{l}\text { Err_t } t_{p} \\
\text { (h) }\end{array}$ & $\begin{array}{l}\text { Err_ } Q_{p} \\
(\%)\end{array}$ \\
\hline SL-PN Model 1 & 0.861 & 244.502 & 0.74 & -2.5 & 3.31 & 0.99 & 60.039 & 0.99 & 0 & 4.729 \\
\hline SL-PN Model 2 & 0.789 & 259.171 & 0.71 & -3.5 & 12.6 & 1 & 15.869 & 1 & 0 & -0.69 \\
\hline SL-PN Model 3 & 0.977 & 90.744 & 0.96 & 0 & 7.18 & 0.99 & 88.678 & 0.97 & 0 & 13.72 \\
\hline
\end{tabular}




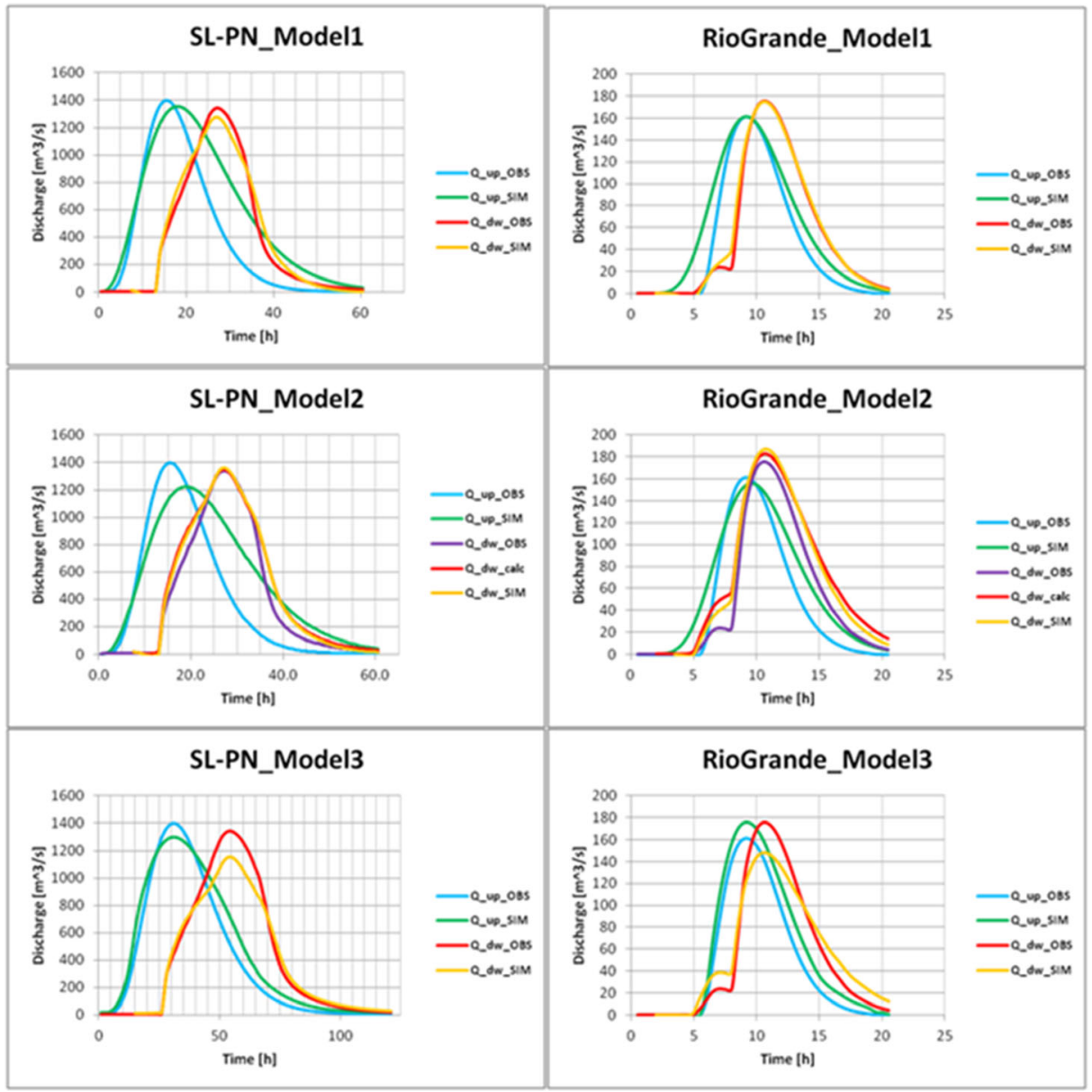

Fig. 7 Generated upstream and downstream hydrographs for all simulated flood events based on MIKE 11 in the Santa Lucia-Ponte Nuovo river reach (left) and in the Rio Grande river reach (right) by Model 1-2-3

\subsubsection{Rio Grande River Reach}

For this case study, the hydraulic information at channel ends are obtained by routing the upstream inflow by MIKE11 along with the lateral flow given by a hydrologic

Table 11 Performance measures for Rio Grande river reach for Model 1-2-3

\begin{tabular}{|c|c|c|c|c|c|c|c|c|c|c|}
\hline \multirow[t]{2}{*}{ River reach } & \multicolumn{5}{|c|}{ Upstream } & \multicolumn{5}{|c|}{ Downstream } \\
\hline & $\mathrm{R}^{2}(-)$ & $\begin{array}{l}\text { RMSE } \\
\left(\mathrm{m}^{3} / \mathrm{s}\right)\end{array}$ & NS (-) & Err_t $t_{p}(h)$ & $\begin{array}{l}\text { Err_Q } Q_{p} \\
(\%)\end{array}$ & $\mathrm{R}^{2}(-)$ & $\begin{array}{l}\text { RMSE } \\
\left(\mathrm{m}^{3} / \mathrm{s}\right)\end{array}$ & NS (-) & Err_t ${ }_{p}(h)$ & $\begin{array}{l}\text { Err_Q } Q_{p} \\
(\%)\end{array}$ \\
\hline Rio Grande Model 1 & 0.938 & 18.887 & 0.89 & 0 & 0.01 & 1 & 4.494 & 1 & 0 & 0.552 \\
\hline Rio Grande Model 2 & 0.942 & 19.863 & 0.89 & -0.5 & 3 & 1 & 5.715 & 0.95 & -1 & -2.11 \\
\hline Rio Grande Model 3 & 0.991 & 12.787 & 0.95 & 0 & -8.8 & 0.98 & 13.998 & 0.95 & 0 & 15.69 \\
\hline
\end{tabular}


model developed by Brocca et al. (2011). The upstream hydrograph and lateral flow refer to the response to a synthetic hyetograph rainfall of the basin subtended from the upstream section $\left(150 \mathrm{~km}^{2}\right)$ and of the intermediate basin $\left(190 \mathrm{~km}^{2}\right)$, respectively. Figure 7 (right) shows the results of reverse flood routing simulations for the three models. Table 11 shows the performance measures for both cases. In terms of error in time to peak and peak discharge at channel ends, it is found not exceeding $1 \mathrm{~h}$, and $16 \%$, respectively. Model 3 is found to perform slightly poorer and this may be tied to the lateral flow assumption considered uniform. This aspect will be the focus of further analyses.

\section{Conclusions}

Based on the analysis carried out in this work, the following findings can be drawn:

1. The reverse flood routing model developed for three different hydrometric configurations can be conveniently applied to estimate discharge at unguged sites, avoiding a solution of the problem based on routing of flood or rainfall-runoff transormation. This has a great advantage considering that neither rainfall time series are necessary for the analysis nor spatial topographical data of the river reach are required and this entails a considerable economic benefit.

2. The differences of performance among the models can be ascribed to the structure of them along with information that they have used. Model 2 is expected to be less accurate than the other considering less information used by it, i.e., only the stage hydrograph at downstream end. For Model 3, the wave travel time is estimated in a robust way for the availability of stage hydrographs at both channel ends and this might give to the method greater robustness. However, if the lateral flow is not quite uniform the performances may drop and this will be the focus of a further new research.

3. The upstream hydrographs successfully are simulated for different length of river reaches and with significant intermediate drainage areas, regardless the hydrometric configuration considered. However, Model 1 and 2 show lower performance and this is expected considering that no information of stage is used at upstream end.

4. High peak flood hydrographs, which have crucial importance from an engineering perspective, can be confidently generated by the model using only the downstream end information also when only stages are recorded there. This is of paramount importance if extreme events are of interest from a hydrological point of view and in particular to extrapolate rating curves for high stages.

5. Performance of model can be low for generating small magnitude peak hydrographs. This may be due to the wave travel time that might be affected by a more significant velocity gradient along a river reach. This argument however will be the object of the future investigation.

6. Finally the synthetic test shows the benefit to use the proposed reverse flood routing in comparison with the hydraulic models which require a detailed channel geometry along with the knowledge of lateral flow which can be given only by a rainfall-runoff transformation. 


\section{References}

Artichowicz W, Szymkiewicz R (2009) “Inverse integration of open channel flow equation". International Symposium on Water Management and Hydraulic Engineering, Ohrid, Macedonia

Aytek A, Kisi O (2008) A genetic programming approach to suspended sediment modelling”. J Hydrol 351(3-4): 288-298

Barbetta S, Franchini M, Melone F, Moramarco T (2012) Enhancement and comprehensive evaluation of the Rating Curve Model for different river sites". J Hydrol 464-465:376-387

Brocca L, Melone F, Moramarco T (2011) Distributed rainfall-runoff modelling for flood frequency estimation and flood forecasting". Hydrol Process 25(18):2801-2813. doi:10.1002/hyp.8042

Bruen M, Dooge JCI (2007) Harmonic analysis of the stability of reverse routing in channels". Hydrol Earth Syst Sci 11(1):559-568

Cheng CT, Ou CP, Chau KW (2002) Combining a fuzzy optimal model with a genetic algorithm to solve multiobjective rainfall-runoff model calibration". J Hydrol 268(1-4):72-86

Cheng CT, Wu XY, Chau KW (2005) Multiple criteria rainfall-runoff model calibration using a parallel genetic algorithm in a cluster of computer". Hydrol Sci J 50(6):1069-1088

Cheng CT, Zhao MY, Chau KW, Wu XY (2006) Using genetic algorithm and TOPSIS for Xinanjiang model calibration with a single procedure. J Hydrol 316(1-4):129-140

D’Oria M, Tanda MG (2012) Reverse flow routing in open channels: A Bayesian geostatistical approach". J Hydrol 460-461:130-135

Danish Hydraulic Institute (DHI) (2003) “User's manual and technical references for MIKE 11" (version 2003). Hørsholm, Denmark

Das A (2009) Reverse stream flow routing by using Muskingum models". Sadhana 34(3):483-499

Dooge JCI, Bruen M (2005) Problems in reverse routing”. Acta Geol Pol 53(4):357-371

Eli RN, Wiggert JM, Contractor DN (1974) Reverse flow routing by the implicit method". Water Resour Res 10(3):597-600

Goldberg DE (1989) Genetic algorithms for search, optimization, and machine learning". Addison-Wesley, USA

Goldberg DE (1999) Genetic Algorithms". Addison-Wesley, USA

Guan J, Aral MM (2005) Remediation System Design with Multiple Uncertain Parameters using Fuzzy Sets and Genetic Algorithm". J Hydrol Eng 10(5):386-394

Hejazi MI, Cai XM, Borah DK (2008) Calibrating a watershed simulation model involving human interference: an application of multi-objective genetic algorithms". J Hydroinf 10(1):97-111

Jain A, Bhattacharjya RK, Sanaga S (2004) Optimal design of composite channels using genetic algorithm". J Irrig Drain Eng 130(4):286-295

Liong SY, Chan WT, ShreeRam J (1995) Peak flow forecasting with genetic algorithm and SWMM". J Hydraul Eng ASCE 121(8):613-617

Moramarco T, Saltalippi C, Singh VP (2004) Estimation of mean velocity in natural channels based on Chiu's velocity distribution equation". J Hydrol Eng 9(1):42-50

Moramarco T, Melone F, Singh VP (2005a) Assessment of flooding in urbanized ungauged basins: a case study in the Upper Tiber area, Italy". Hydrol Process 19(10):1909-1924

Moramarco T, Barbetta S, Melone F, Singh VP (2005b) Relating local stage and remote discharge with significant lateral inflow". J Hydrol Eng 10(1):58-69

Moramarco T, Pandolfo C, Singh VP (2008) Accuracy of kinematic wave approximation for flood routing. II. Unsteady analysis". J Hydrol Eng 13(11):1089-1096

Palisade Corporation (2013) “Evolver, the genetic algorithm solver for Microsoft Excel 2012”. Newfield, New York

Perumal M, Moramarco T, Sahoo B, Barbetta S (2007) "A methodology for discharge estimation and rating curve development at ungauged river sites". Water Resour Res, 43, W02412, doi:10.1029/2005WR004609, 2007, pp. 22

Perumal M, Moramarco T, Sahoo B, Barbetta S (2010) "On the practical applicability of the VPMS routing method for rating curve development at ungauged river sites”. Water Resour Res, 46, W03522, doi:10.1029/ 2009WR008103, 2010, pp. 9

Sahoo B (2013) Field application of the multilinear Muskingum discharge routing method". Water Resour Manag 27(2013):1193-1205. doi:10.1007/s11269-012-0228-5

Sahoo B, Perumal M, Moramarco T, Barbetta S (2014) Rating Curve Development at Ungauged River Sites using Variable Parameter Muskingum Discharge Routing Method". Water Resour Manag 28(2014):37833800. doi:10.1007/s11269-014-0709-9

Sen Z, Oztopal A (2001) Genetic algorithms for the classification and prediction of precipitation occurrence". Hydrol Sci J 46(2):255-267

Singh RM, Datta B (2006) Identification of Groundwater Pollution Sources Using GA-based Linked Simulation Optimization Model". J Hydrol Eng 11(2):101-109 
Szymkiewicz R (1996) Numerical stability of implicit four-point scheme applied to inverse linear flow routing". J Hydrol 176:13-23

Taji K, Miyake T, Tamura H (1999) "On error back propagation algorithm using absolute error function". Int Conf Syst Man Cybern IEEE SMC '99Confer Proc 5:401-406

Tayfur G (2009) GA-optimized method predicts dispersion coefficient in natural channels". Hydrol Res 40(1): $65-78$

Tayfur G (2012) Soft Computing in Water Resources Engineering”. WIT Press, Southampton

Tayfur G, Moramarco T (2008) "Predicting hourly-based flow discharge hydrographs from level data using genetic algorithms". J Hydrol 352(1-2):77-93

Tayfur G, Singh VP (2011) Predicting Mean and Bankfull Discharge from Channel Cross-Sectional Area by Expert and Regression Methods". Water Resour Manag 25(5):1253-1267

Tayfur G, Moramarco T, Singh VP (2007) Predicting and forecasting flow discharge at sites receiving significant lateral inflow". Hydrol Process 21:1848-1859

Tayfur G, Barbetta S, Moramarco T (2009) Genetic Algorithm-Based Discharge Estimation at Sites Receiving Lateral Inflows". J Hydrol Eng 14(5):463-474

Wu CL, Chau KW (2006) A flood forecasting neural network model with genetic algorithm". Int J Environ Pollut 28(3-4):261-273 